\title{
Association of Urine Ketones with Exercise
}

\author{
Muhammad Imran Qadir, Hurain Shaukat* \\ Institute of Molecular Biology and Biotechnology, Bahauddin Zakariya University, Multan, Pakistan
}

*Corresponding Author: Hurain Shaukat, Institute of Molecular Biology and Biotechnology, Bahauddin

Zakariya University, Multan, Pakistan

\begin{abstract}
This project was about Urine Ketone with exercise and total 90 subjects were participated studied in Bahuddin Zakariya University, Multan, Pakistan. Urine Ketones relates with the blood sugar level because higher the level of ketones higher will be the sugar level. But sometimes it leads to the coma or even death. Exercise is important factor that effects on it. And also the sugar test is performed.
\end{abstract}

Keywords: Urine ketones, Exercise, Sugar level, Diabetes

\section{INTRODUCTION}

Sugar level relates to the sugar ketones. It cause high sugar level then the ketones level is also high. And causes type 1 and type 2 which is important to check the ketones. Higher level of ketones indicates diabetes and then leads to coma or even death. Insulin which is biotechnological product uses for lowering of blood sugar level. People without diabetes having ketones in urine if the body is using fat or fuel. (1)

Exercise retains the body balance. Persons who are interested in natural health they surely do some physical exercise such as fitness walking. We should adopt the active life style better than physical exercise to improve our natural health. (2)

\section{Materials ANd Methods}

To find out the urine ketone level the test is performed so that to identify the ketones in urine. High level of ketones in urine may indicate the diabetes ketoacidosis it's a severe complication of diabetes. Light nutritional ketosis indicate between 0.5 to $1.5 \mathrm{mmol} / \mathrm{L}$.

\section{Project Design}

A Survey was prepared about the exercise

\section{Statistical Analysis}

It were done by using MS Excel

\section{RESULTS AND DISCUSSION}

This project was used to co relate the urine ketones with the exercise is given in Table \#1 as follows. And in this study data collected from the university students in which male female participated so that the views about the relation of urine ketones with exercise shows the negative or positive results. About $64.4 \%$ people show positive results while $35.5 \%$ people shows negative results.

Table1. Association of Urine ketones with Exercise as follows

\begin{tabular}{|c|c|}
\hline Urine ketones likeness with Exercise & Urine ketones dislikeness with exercise \\
\hline $64.4 \%$ & $35.5 \%$ \\
\hline
\end{tabular}

\section{CONCLUSION}

Questionnaire based studies have been given important research outcomes (3-10).Ketones produced in the body when people utilize fats. Fat important source of energy but when it is used by the body during exercise it may be harmful. It causes the lack of energy or weakness. Altered consciousness or disorientation too. 


\section{REFERENCES}

[1] Qadir MI, Malik SA (2010) Comparison of alterations in red blood cell count and alterations in hemoglobin concentration in patients suffering from rectal carcinoma undergoing 5-fluorouracil and folic acid therapy. Pharmacologyonline, N1 3: 240-243.

[2] Qadir MI, Noor A (2018) Anemias. Rare \& Uncommon Diseases. Cambridge Scholars Publishing. Newcastle, England. ISBN: 978-1-5275-1807-0.

[3] Qadir MI, Javid A (2018) Awareness about Crohn's Disease in biotechnology students. Glo Adv Res J Med Medical Sci, 7(3): 062-064.

[4] Qadir MI, Saleem A (2018) Awareness about ischemic heart disease in university biotechnology students. Glo Adv Res J Med Medical Sci, 7(3): 059-061.

[5] Qadir MI, Ishfaq S (2018) Awareness about hypertension in biology students. Int J Mod Pharma Res, 7(2): 08-10.

[6] Qadir MI, Mehwish (2018) Awareness about psoriasis disease. Int J Mod Pharma Res, 7(2): 17-18.

[7] Qadir MI, Shahzad R (2018) Awareness about obesity in postgraduate students of biotechnology. Int J Mod Pharma Res, 7(2): 14-16.

[8] Qadir MI, Rizvi M (2018) Awareness about thalassemia in post graduate students. MOJ Lymphology \& Phlebology, 2(1): 14-16.

[9] Qadir MI, Ghalia BA (2018) Awareness survey about colorectal cancer in students of M. Phil Biotechnology at Bahauddin Zakariya University, Multan, Pakistan. Nov Appro in Can Study, 1(3): NACS.000514.2018.

[10] Qadir MI, Saba G (2018) Awareness about intestinal cancer in university student. Nov Appro in Can Study, 1(3): NACS.000515.2018.

Citation: Muhammad Imran Qadir, Hurain Shaukat, "Association of Urine Ketones with Exercise" International Journal of Research Studies In Biosciences (Ijrsb), Vol. 7, no. 5, pp. 34-35, 2019. http://Dx.Doi.org/10.20431/2349-0365.0705005

Copyright: (C) 2019 Authors. This is an open-access article distributed under the terms of the Creative Commons Attribution License, which permits unrestricted use, distribution, and reproduction in any medium, provided the original author and source are credited. 